\title{
Stability analysis of underground openings for extraction of natural stone
}

\section{Stabilnostna analiza podzemnih prostorov za pridobitev okrasnega kamna}

\author{
Karmen FIFER BIZJAK
}

Zavod za gradbeništvo, Dimičeva 12, 1000 Ljubljana, Slovenia

Key words: numerical model, rock mechanics, underground openings Ključne besede: numerični modeli, mehanika hribin, podzemni prostori

\section{Kratka vsebina}

Pridobivanje naravnega kamna s podzemnimi komorami je v svetu in pri nas še vedno v zelo nizkem deležu v primerjavi s povr'inskim odkopavanjem. Ob omejenih ekonomskih zalogah naravnega kamna in ostrejših ekoloških zahtevah je podzemno pridobivanje aktualna alternativa.

Dimenzije podzemnih prostorov se določijo na osnovi stabilnostnih analiz. Bistvenega pomena je, da se ugotovi mehanizem možnih porušitev v podzemnem prostoru. Na podlagi tega se izbera primerna stabilnostna analiza. V mehaniki hribin se zelo pogosto uporablja numerična zvezna analiza. Slabost analize je v tem, da ni možno simulirati sistemov prelomov. V zadnjih letih je velik razvoj doživela numerična analiza ločenih elementov, ki omogoča stabilnosti izračun podzemnih prostorov $\mathrm{v}$ zmerno razpokani hribini. $\mathrm{V}$ predstavljenem primeru izgradnje podzemnih prostorov kamnoloma Hotavlje so podani rezultati obeh analiz. Ugotovljeno je, da je zvezna analiza primerna za preverjanje globalne stabilnosti podzemnega prostora, z nadaljno analizo pa dobimo natančnejše izračune o stabilnosti blokov v okolici izkopa. Za preverjanje stabilnosti posameznih blokov in podpornega sistema za posamezen blok, pa je še vedno dovolj natančna analitična blokovna analiza. Prvi pogoj za zanesljivo stabilnostno analizo je dovolj vhodnih podatkov o geomehanskih lastnostih hribine. Za to so potrebne terenske in laboratorijske preiskave in geotehnične meritve. Na podlagi večjega števila izdelanih stabilnostnih analiz je bila za podzemne prostore kamnoloma Hotavlje ugotovljena največja širina podzemnih prostorov $12 \mathrm{~m}$.

\begin{abstract}
Extraction of natural stone is usually carried out in surface quarries. Underground excavation is not a frequently used method. Due to the restrictive environmental legislature and limited stores of natural stone, underground extraction has become quite an interesting alternative. Dimensions of underground openings are determined with stability analyses. Prior to starting a numerical analysis of a large underground opening it is very important to determine the mechanism of failure and set up a proper numerical model. The continuum method is usually used in rock mechanics. A disadvantage of this calculation is that it cannot be applied to a large number of joints. Other methods are preferred, such as the numerical discrete method, which allows joint systems to be involved into calculations. The most probable failure of rock with several joint systems is block sliding. In the example of the marble of Hotavlje both methods were used. It was established that the continuum method is convenient for the global stability prediction of the underground opening. Further discrete method enable the block stability calculation. The analytical block analysis is still accurate for the a stability calculation of single block. The prerequisite for a good numerical analysis is sufficient quality data on geomechanical properties of rock. In-situ tests, laboratory tests and geotechnical measurements on the site are therefore necessary. Optimum dimensions of underground chambers in the Quarry of Hotavlje were calculated by using several numerical models, and the maximum chamber width of $12 \mathrm{~m}$ was obtained.
\end{abstract}




\section{INTRODUCTION}

Extraction of natural stone in underground chambers is quite rare in Slovenia and also in other countries of the world. Surface excavation is still in the majority everywhere. Underground excavation becomes more and more interesting because of limited stores of natural stone and rigorous environmental regulations.

There always exists a possibility that rock is not appropriate for underground excavation. Therefore, the decision for such technology shall be based on geotechnical investigations of a rock massive. In the first stage, maximum dimensions of chambers and galleries shall be estimated using a preliminary analysis. Usually RMR and Q rock mass classification are used. In this paper the term gallery is used for an underground excavation of a height of $4 \mathrm{~m}$ and the term chamber for a higher one. The jointed system of rock shall be identified and mapped during the engineering geological work on the field. Several in-situ and laboratory geotechnical investigations shall be carried out to evaluate geotechnical properties of rock.

In the next stage a research gallery shall be excavated and various geotechnical equipment installed in it. The use of extensometers, measuring anchors, crack-meters, convergence profiles and $3 \mathrm{D}$ measurement devices is recommended in our experience. Geotechnical measurements in a gallery can supply a very important information on the deformation and stress field and provide input data for the stability analysis.

\section{NUMERICAL METHODS}

The most commonly applied numerical methods in rock mechanics are continuum method and discrete method. The choice of methods depends on many specific problems, mainly on the problem scale and fracture system geometry.

\subsection{Continuum method}

Several numerical programs are available for the continuum calculation. One of them, FLAC $2 \mathrm{D}$, is presented in the paper. It is an explicit finite difference program (FDM) that performs Lagrangian analysis. The general calculation sequence embodied in this

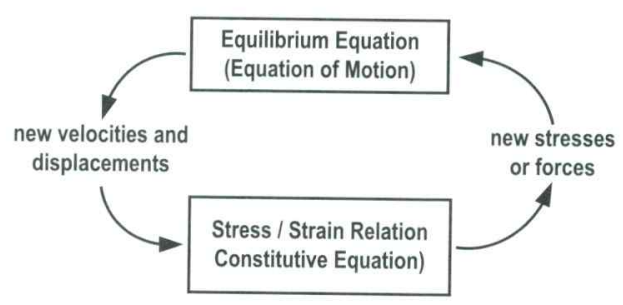

Figure 1. Basic explicit calculation cycle

program is illustrated in Figure 1. This procedure first invokes the equations of motion to derive new velocities and displacements from stresses and forces. Then strain rates are derived from velocities and new stresses from strain rates. One timestep is taken for each cycle. It is important that the timestep is small enough. Deficiency of such calculations lies in the structural analysis. It is almost impossible to consider a moderately number of joint systems. For jointed and fissured rock, the geomechanical properties for the numerical model should be reduced.

\subsection{Discrete method}

The discrete approach is most suitable for moderately fractured rock mass. Recent programs are described as distinct element method (DEM). The program UDEC is presented in the paper. In a distinct element method, a rock mass is represented as an assembly of discrete blocks, and joints as interfaces between distinct bodies. Contact forces and displacements at interfaces are obtained through a series of calculations which are tracing the movement of blocks, the movement being induced by applied loads or body forces in a dynamic process. The dynamic behaviour is represented numerically by a timestepping algorithm.

The distinct method is based on the concept that the timestep is sufficiently small to prevent the propagation of disturbances between discrete elements. Calculations performed by the distinct element method alternate between the application of the force-displacement law to all contacts and Newtonžs second law to all blocks. The force displacement law is used to find out contact forces from known displacements. Newton's second law gives the motion of blocks resulting from known forces acting on them. If 


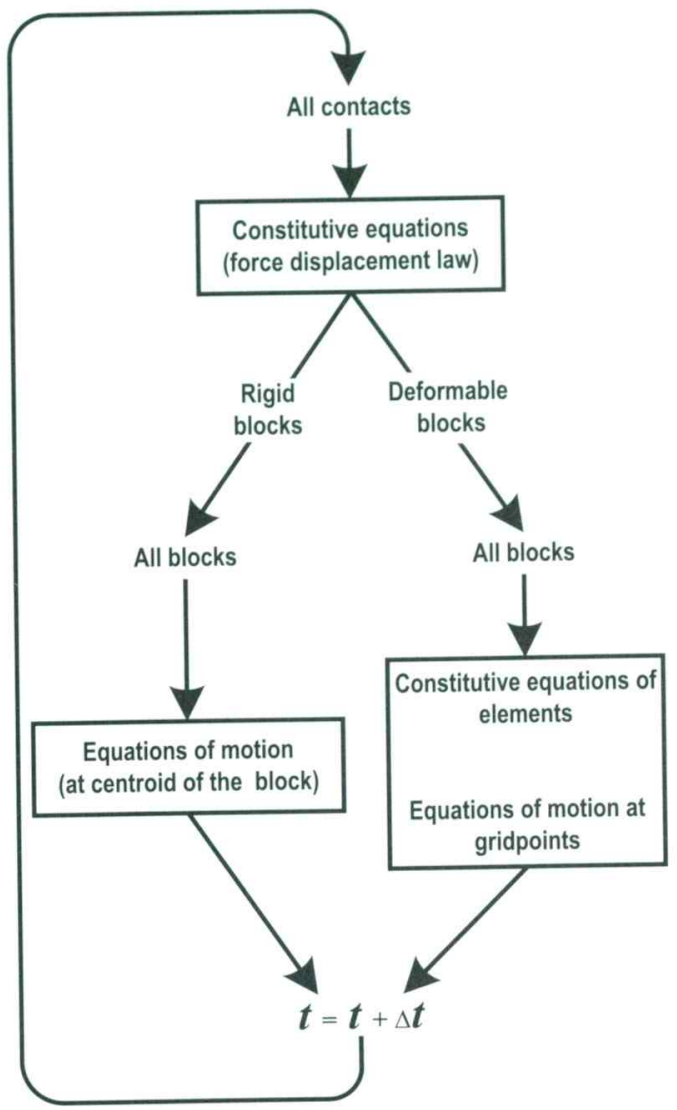

Figure 2. Calculation cycle of the distinct element method

blocks are deformable, the motion is calculated at gridpoints of triangular finite strain elements within blocks. Figure 2 shows schematically the calculation cycle for the distinct element method.

\section{CASE HISTORY: THE QUARRY OF HOTAVLJE}

The Quarry of Hotavljewas the first Slovene quarry which started the underground extraction of natural stone. This natural stone is known as the "Marble of Hotavlje", although it is actually limestone in a lithological sense. Hotavlje quarry is located in the narrow valley of Volašca stream, a few hundred meters north from the village Hotavlje in the Poljanska valley. The quarry is built in the cordevol limestone (Vesel, Senegačnik, 2000). First investigations were started in 1993. According to preliminary analyses, the largest width of an underground opening with a semi-circular ceiling was estimated to $20 \mathrm{~m}$ (Petkov'ek, 1993). Investigations were performed systematically till 2001. Several numerical models, supplied with geological and geotechnical data, were used for calculations. Optimum and safe dimensions of chambers were calculated at the end of the research project. The position of galleries in the middle of the year 2001 is shown on Figure 3 . Three galleries, 8 wide and $4 \mathrm{~m}$ high, were excavated until that time. The length of the longest gallery was $45 \mathrm{~m}$. The west gallery (G3) and middle gallery (G1) were connected with crossbar (P2). Also the middle gallery and east gallery were connected with another crossbar (P1).

\subsection{Investigations performed}

\subsubsection{Engineering geological mapping}

Joint systems were identified by means of the engineering geological mapping. The limestone of Hotavlje was found to be fissured by two systems of joints and additional random fissures on some locations. Open joints or joints with clay were crucial for the possibility of a block failure. There were great variations in the strike and quality of joints. The fact that joints were not continuous throughout the quarry, had a positive effect on underground openings. Although a failure of a separate block might occur in such cases, the underground opening would remain structurally stable.

\subsubsection{In situ investigations}

Several pressuremeter measurements were carried out during the research project. Very high elastic moduli of 21-60 GPa were calculated in the intact rock. They were confirmed by laboratory dynamic ultrasound investigations which gave values of 58-66 $\mathrm{GPa}$. Elastic moduli of fissured rock were much lower, their values dropping down to 5-10 GPa.

Laboratory geotechnical tests

The weakness of geotechnical laboratory tests lay in the fact that intact specimens were tested. The limestone of Hotavlje showed quite a high uniaxial compressive 
strength of $15-93 \mathrm{MPa}$. Its tensile strength was between 5 and $10 \mathrm{MPa}$. Triaxial laboratory tests performed on five samples showed that their angle of friction was $33^{\circ}$ and cohesion $46 \mathrm{MPa}$. The cohesion value was very high. But as the limestone of Hotavlje is very fissured in reality, a lower cohesion value had to be used for the stability analysis.

\subsubsection{Geotechnical measurements}

Geotechnical measurements are used for the observation of the deformation field around an excavation. In this way, they are very important for the monitoring of stability and safety of underground excavations. The following geotechnical equipment was installed into galleries:

- convergence profiles for measuring relative displacements between the sides and between the ceiling and the floor of a gallery. They were installed on portals and close to extensometer profiles.

- extensometer profiles for measuring deformations around the excavation. Two extensometer profiles were installed. The lengths of extensometers were 1.5, 3 and 6 $\mathrm{m}$.

- crack-meters for measuring distances between the sides of joints. Five crackmeters were installed across the largest joints running through a gallery.

The results of convergence measurements showed that the maximum displacement between the two sides of a gallery amounted to $1.5 \mathrm{~mm}$. The maximum displacement was observed at the portal of the west gallery and at the crossbar P2. Deformations obtained from extensometers and crack-meters

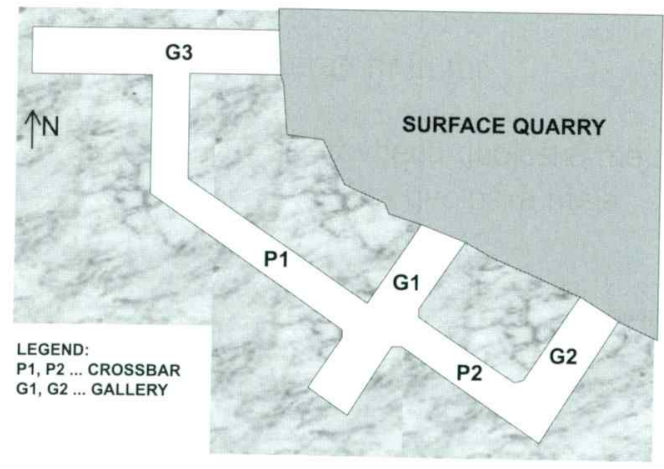

Figure 3. Plan of the underground galleries did not exceed $0.5 \mathrm{~mm}$. The last measurements of all profiles in the middle of 2001 confirmed the stability of galleries.

\subsection{Stability analysis of underground open- ings of the Quarry of Hotavlje}

Several numerical analyses were made on the basis of laboratory tests, field investigations and geotechnical measurements. It is recommended to make a numerical backanalysis for a model to calibrate it according to the real situation on the field. Numerical back-analyses were carried out for the existing galleries. In the next step, extension and deepening of the excavation was simulated.

Preliminary analyses were made on the basis of two rock classifications, the RMR (Bieniawski, 1989) and the Q (Barton et al., 1974) rock classification. The quality of rock was estimated by considering parameters of uniaxial strength, RQD index, water conditions, joint system and quality of joints. The limestone of Hotavlje was classified into the group II, which means that rock was of a good quality for underground (with RMR classification).

As already mentioned, several numerical models are available for the calculation. In the paper the finite difference model will be presented as a continuum method and the distinct element model as a discrete method.

\subsubsection{Finite difference method (FDM)}

The finite difference method with the Mohr-Coulomb calculation was used in the first step. The method is one of the most popular numerical methods in rock engineering.

The ratio $k$ between the horizontal stress field and vertical stress field depends on depth and tectonical conditions of a region. Data from measurements in different depths and different parts of the word present the value of the coefficient $k$ between 1 and 2.5 (Hoek \&Brown, 1996). In our calculations, the value of $k=1$ was adopted, because the best results were calculated in comparrison with measured results..

In first numerical simulations, several calculations were done for massive unfractured rock. As its geomechanical properties are high, the results of calculations showed that openings were stable at 


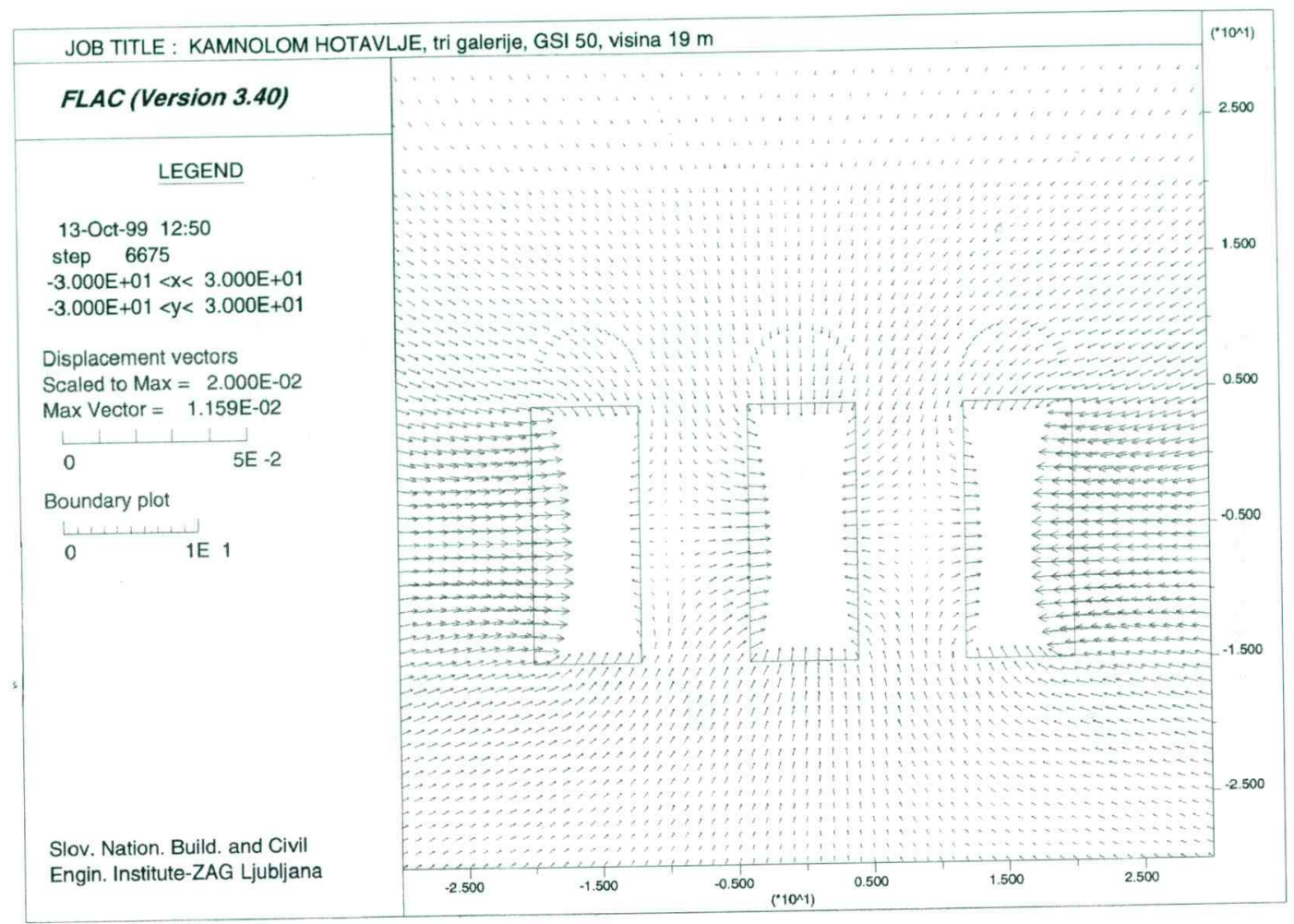

Figure 4. Displacements around galleries (continuum method)

relatively great dimensions. A chamber with the semi-circular ceiling was stable even at the width of $16 \mathrm{~m}$. However, the limestone of Hotavlje is fractured in reality. Consequently, geomechanical properties of fractured rock were reduced in the next step by using the GSI index (Marinos \& Hoek, 2000). GSI is a new classification method very appropriate for fractured rock. The GSI index can be estimated from diagrams for different types of rock, fracture systems and fracture qualities. Geomechanical properties were then calculated on the basis of the GSI index and lithological parameters. The value of the GSI index estimated from the engineering geological mapping amounted to 50 . The following geomechanical properties, were used in the numerical model:

$\mathrm{E}$ (elastic modulus) $6.32 \mathrm{GPa}$

$v$ (poisson's ratio)

$\gamma$ (unit weight) $0.24 \mathrm{KN} / \mathrm{m}^{3}$

$\varphi$ (angle of friction)

$c$ (cohesion)
Vectors of deformations for three chambers, for example, are presented in Figure 4. The height of the respective chambers was $19 \mathrm{~m}$ and the width $8 \mathrm{~m}$. The maximum calculated deformation was $12 \mathrm{~mm}$. Chambers with the width of $16 \mathrm{~m}$ were stable to the depth of $30 \mathrm{~m}$ too, but only in the case their ceiling was semi-circular.

\subsubsection{Distinct element method (DEM)}

The calculation based on the distinct element numerical method can provide block deformations and deformations in joints between blocks. The limestone of Hotavlje is jointed into several large blocks. And every single block is further divided by close fissures or fissures filled with silicates. These fissures are not dangerous for the stability of the whole excavation, but they bring about lower geomechanical properties of individual blocks. The GSI value of 68 was estimated for the blocks. The following geomechanical properties, based on the GSI 
calculation, were used in the numerical model:

E (elastic modulus) $21.8 \mathrm{GPa}$

$\checkmark$ (poisson's ratio)

$\gamma$ (unit weight)

$\varphi$ (angle of friction)

$c$ (cohesion)

The Mohr-Coulomb calculation was used for blocks and joints. This mathematical model enables only a two-dimensional calculation. Accordingly, joints have to be projected on the plane perpendicular to the gallery. It is impossible to consider all joints and fissures in the calculation. The problem must be simplified by considering only joints which are relevant for the stability of an underground excavation. In addition, all joints are highly variable with respect to dimensions, strike and quality. Continuous joints without breaks shall be used for the numerical method. It is a conservative cal- culation, because more blocks are formed in this case and more of them are critical for sliding into the excavation. Joints parallel and perpendicular to the dinaritic strike shall be simulated in the numerical calculation. Beside two system of joints, several random joints exist too.

A bigger problem is the estimation of geomechanical properties of joints. Laboratory tests of jointed rock are limited. Some theoretical and empirical equations exist for the normal stiffness $(K n)$ and shear stiffness $(K s)$. The best way, to our opinion, is the numerical back-analysis. Numerical backanalyses were applied to the convergence profiles which had been installed into the galleries. Geomechanical properties required by the numerical models were changed systematically until the measured displacements were calculated. By using this procedure, the following geomechanical properties were obtained for the joints:

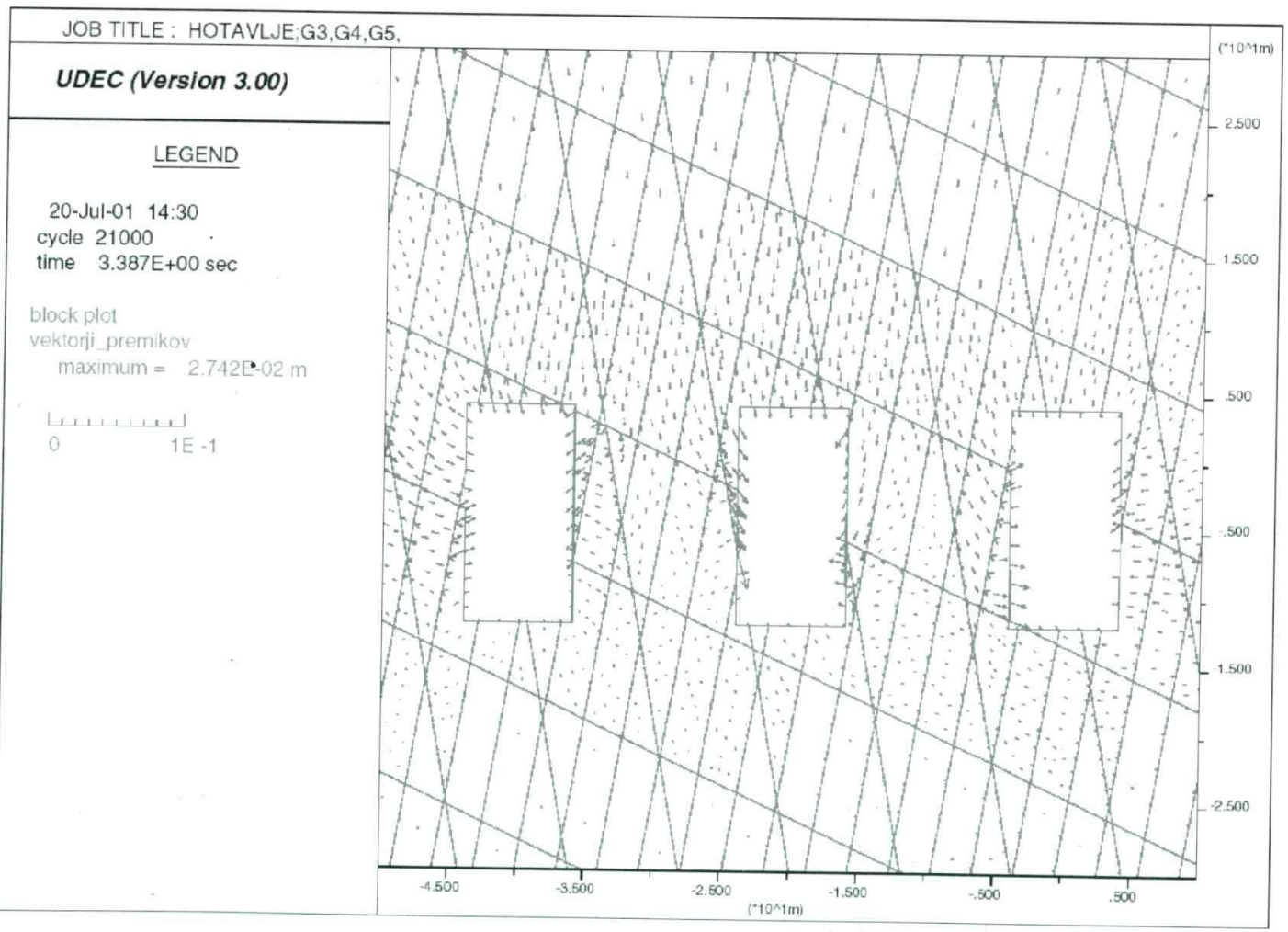

Figure 5. Displacements around galleries (discrete method) 
Kn (normal stiffness) $2.5 \mathrm{GPa}$

Ks (shear stiffness) $2.5 \mathrm{GPa}$

$\varphi$ (angle of friction) $25^{\circ}$

$c$ (cohesion) 0

As in previous calculations, the value of the coefficient $k$ equal to 1 was adopted.

In the case of unstable blocks a support system with anchors shall be foreseen. The orientation and number of anchors depend on the individual block. The anchors of $8 \mathrm{~m}$ length with the following properties were used in calculations:

1 (length) ...................... $8 \mathrm{~m}$

$\phi$ (diameter) ..................... $38 \mathrm{~mm}$

E (elastic modulus) .................... $200 \mathrm{GPa}$

$y$ (yield tension) $300 \mathrm{KN}$

The ratio of width to depth is very important for the stability of a chamber. Data of known underground openings all over the world were collected in a special database (Kaiser, 2000). The results indicated that the majority of large underground openings was stable, provided the widthto-depth ratio was 2 . These results were confirmed by our calculations too. Chambers in the limestone of Hotavlje were stable up to the width of $12 \mathrm{~m}$. In the west side of the quarry, there is a higher density of joints and their orientation more unfavourable for the gallery. In that region the greatest width of chambers was $8 \mathrm{~m}$. In all simulations the greatest displacements occurred in joints between blocks. Maximum displacements were about few centimetres there. An example of three galleries having the width of $8 \mathrm{~m}$ is presented on Figure 5. Maximum displacements were calculated on the sides of unstable blocks which were local supported by anchors.

\subsubsection{Analytical block analysis}

More information on block stability of single block can be obtained from the block analysis based on the block theory. The geotechnical stability of a block is calculated from the strike, dip and geotechnical properties of joints. Joint systems observed in the excavated galleries rvere used in these calculations. Several simulations were made for galleries of different dimensions. Almost all blocks could be stabilized by using long enough anchors.

After having performed calculations with the mathematical model and block analysis, it became clear that the most probable type of failure would be the block failure.

\subsection{Comparisons of the continuum method and the discrete numerical method}

Several numerical analyses were carried out with different models. Calculations showed that stability could be expected in cases of underground chambers of $12 \mathrm{~m}$ width and depth of 2 times the width. In all calculations, the safety factor of 1.5 was taken into consideration. The comparison between the continuum (FDM) and the discrete method (DEM) was of interest for the detection of regions with greatest deformations. In the first case, the greatest deformations were obtained on both sides of a chamber. When the continuum method is applied to fissured rock, lower properties of rock shall be considered, because they are calculated by using the GSI index. The whole rock massive is acting as a solid body and consequently, the greatest deformations are calculated on critical places of excavation, i.e. on the ceiling or on the sides. Numerical results indicate the possibility of the collapse of the sides or the ceiling of a chamber, if the latter is too wide.

The calculation using the discrete model is closer to reality. Several joint systems are forming a region divided into several blocks. The rock is a high quality one, but joints are open or filled with stiff clay. Unstable blocks might fail under such geological conditions. Maximum deformations are calculated on the sides of chambers too, but only in the region of unstable block. However, an optimum support system can be provided in this case too. The discrete method enable detailed prediction of the block stability around the underground opening.

\section{Conclusions}

Based on practical experiences gained by underground excavation in the Quarry of Hotavlje, the following conclusions can be drawn:

- The prerequisite for a good stability analysis is the input of quality data. Laboratory and in-situ measurements are necessary to obtain them.

- The most important is to detect the mechanism of failure

- In the first stage the global stability is calculated with numerical continuum 
method and in the next stage the stability of blocks with discrete method.

- The best method for the evaluation of geomechanical properties of joints is the numerical back-analysis. In order to calibrate this calculation model, geotechnical measurements shall be carried out.

- It is utterly important to perform the geological mapping during the chamber excavation. The aim of the mapping is to record any new joints which might affect the chamber stability. Such joints are open and clayfilled joints. Special attention shall be paid to continuous joints running through the top and the sides of a chamber. If a block can be formed, its stability shall be analysed by means of the analytical block analysis. The block analysis shall be used to calculate the optimum supporting system for the individual block.

- Continuous geotechnical measurements are very important for the safety of excavation. In the case of greater deformations as predicted from calculations, the stability of a chamber shall be checked by using new data.

Safety is of the utmost importance for the excavation of underground chambers. On the other hand, dimensions of chambers should be appropriate for the economic extraction. The optimum and safe dimensions of the underground openings can be achieved by detailed geological mapping, systematical geotechnical measurements and proper numerical calculations.

\section{References:}

Bieniawski, Z.T. 1989: Engineering rock mass classifications. New York:Willey.

Barton, N.R., Lien, R. \& Lunde, J. 1974: Engineering classification of rock masses for the design of tunnel support. Rock Mech. 6(4), 189239 .

Carvalho, J. \& Hoek, E. 1992: Unwedge useržs Guide, ver.2.3, Rock Engineering Group, University of Toronto.

Hoek, E.\& Brown 1996: Underground Excavation in Rock. E\&FN Spon, London.

Itasca, 2000: Fast Lagrangian Analysis of Continua - User's Manual. Itasca Counsulting Group, Minneapolis

Itasca, 1996: Universal Distinct Element Code - User's Manual. Itasca Counsulting Group, Minneapolis.

Kaiser, P.K., Diederichs, M.S., Martin, C.D., Sharp, J. \& Steiner, W. 2000: Proceeding of the Internations Conference on Geotechnical \& Geological Engineering, Melbourne, Australia. Balkema.

Marinos, P., Hoek, Evert, 2000. GSI: A geologically friendly toll for rock mass strength estimation. Proceeding of the Internation Conference on Geotechnical \& Geological Engineering, Melbourne, Australia. Balkema.

Petkovšek, B. 1993: Geotehnična ocena širine podzemnega prostora za kamnolom Hotavlje. Arhiv GeoZS, Arhiv ZAG, Ljubljana.

Vesel, J. \& Senega čnik, A. 2000: Raziskave naravnega kamna na širšem območju Hotavelj. Arhiv GeoZS, Ljubljana. 